\title{
The Effectiveness of E-Book App Story Telling of Traditional Game Story Series to Increase the Attachment between Parents and Children
}

\author{
Nofrans Eka Saputra \\ 'Departement of Psychology, Jambi University/ Indonesia \\ nofransekasaputra@unja.ac.id \\ Yun Nina Ekawati \\ ${ }^{2}$ Departement of Psychology, Jambi University/ Indonesia \\ yun_nina.e@unja.ac.id
}

\begin{abstract}
The involvement of parents to tell story to the children takes important role to increase attachment. This research aimed to figure to examine the effectiveness of traditional game story series e-book app to increase the attachment between parents and children. The method used was quasi experiment with pre-post control group design. The population of this research consists of 32 kindergarten students which were split to experimental group and controlled group. The experimental group was given storytelling treatment through e-book app series. To measure the result, there was attachment scale used in pretest and posttest. The data was analyzed by using independent $t$ test sample and paired $t$ test sample. The result of the research showed that there was significant attachment between pretest and posttest score within experimental group. Meanwhile, within the controlled group, no significant attachment was found. It can be concluded that traditional game story e-book series can increase the attachment between parents and children. The result of this research supports the previous research conducted by Frude \& Killick (20II) which explains that the story telling done by parent to the children increase the attachment.
\end{abstract}

Keywords: storytelling, parent and children attachment.

Received 23 July 202I/Accepted 25 August 2021 @Author all rights reserved

\section{Introduction}

The impact of Covid-19 which is behavior disorder showed by the insecure attachment of children and the irritable condition of the parents is a complex issue within the family (Rajkumar, 2020). Jiao et al (2020) study shows that this symptom more frequently occurs to $3-6$ years old children. It is aggravated by the implementation of self-isolation and lock down to reduce the spread of Covid-19 (Van Gelder et al., 2020), also the obligation to reduce children social contact with the families and peers including school shut down and home isolation (J. J. Liu et al., 2020), therefore parents are expected to be able to establish attachment to the children to minimize anxiety and anger which adversely affect the their development. 
Attachment theory was stated by Bowlby (Cassidy, 1988; Holmes \& Holmes, 2014) by analyzing the relation pattern between parents and children started from the early childhood. This relation pattern is often known as specific and everlasting created emotional bounding (Ainswort et al., 2015)

According to Bowlby (1969, 1973, 1980) attachment will create "working model" from the attached representative figure. The working model illustrates the concept built by the children about personality, characteristic, and attitude expected from the world and people in it including the children themselves. The flexible and adaptable working model coming from the children repeated daily experience from the attached figure (Cassidy, 1988).

Cassidy (1990) describes that the quality or the security of the representative of this attached relation cannot be separated to the self-representation as whole (Verschueren et al., 1996). If children develop a secure working model from its attached figure, hence children will most possibly to develop the working model as the appreciated self or in reverse, if children develop less secure working model they tend to establish their personal model to be less valued and less appreciated. Further, less secure attachment can contribute to present anxiety to the children (Kern \& Brumariu, 20I4) dysfunctional attitude and low self-esteem (Lee \& Hankin, 2009)

Graci \& Fivush (2017) explain that the existence of attachment within individuals can be stimulated by bridging the narrative expression from their personal experience within pressured situations and asking them to respond and ruminate it. It can be done through the story telling activity (Kiser et al. 2010) The narrative expression within the story telling can be reached through stories having read by the families. The best and worst experience obtained from the story separately can be merged to be a meaningful entity (Killick, 2020). It will grow children attachment toward the attached figure.

The traditional game study has been conducted in several models including traditional game literature model (Saputra \& Ekawati, 2017), story book with picture (book series) (Saputra \& Ekawati, 2019) educational game tools (APE) (Ekawati \& Saputra, 2019; Saputra \& Ekawati, 2021). This model's development is expected to be the baseline research which suits the research need within this digital era. Innovation within the digital era often linked with the technology use in the 
application of the research. Various technologies support science development such as mobile devices and other software. Technology becomes very helpful tools as a learning media in this digital era.

Story telling through digital media becomes an effective method to fulfill the aim of the learning process by using technology advancement and connectivity (Vinayakumar et al., 2018). Digital story telling is a process of combining several digital media including pictures, voice narration, music, contextual or movement to tell the narration or story (Robin, 2008). Digital story telling contains metaphor about concept which is suitable to the children intelligent level (Vivitsou, 2018). Children as digital native is absolutely excited to explore and access many narration by using digital media and obtain metaphor story which obtain exchange of experience from one individual to other individuals, from parent to children or vice versa (Sawyer \& Wilis, 20I I).

Empirically, mobile devices quickly become favorite media alternative for children because of the screen size, mobility, capability to run streaming, interactive capability (Kabali et al., 20I5). Quick adoption of mobile devices by the children tends to be used to design learning media at the age of preschool. (Greenfield in Parish-Morris et al., 20I3).It is including electronic book (E-book). E-book is a combination of the advantages of printed books with the capability of computer technology. It helps children who have no respond to the ordinary printed book (traditional) or who are not willing to read (Maynard, 2010).

The use of e-book which is read on mobile device screen supposes to be accompanied by interactive relationship between parents and children. Parents have to interact with children during reading the e-book to reduce the visual effect which make children miss some parts of the content, as they read printed book (Hill et al., 2016). In the other hand, when adults digitally interact to the children, it achieves affective scaffolding. Affective scaffolding happens when parents motivate and give positive feedback to help children to expand their learning to the thinking level and advanced operation. This underlies the growth of problem solving abilities within the children (Yelland \& Masters, 2007).

This traditional game story e-book application can be applied to the story telling method by using animation and pictured story. Frude \& Killick (20II) explain that the story can introduce children 
to the wider new world and introduce new vocabularies, new concepts, new ideas, and various character and wide scenario spectrum. It expands the kid experience. Story introduces the children to the world aspect which will not be found directly. It can be said that story means 'to expand idea'/ to increase 'knowledge' of children. Further, story helps children to emotionally grow. A lot stories were designed to excite listeners and have strong emotional impact. Children have opportunity to figure out story related to their emotions. It increases emotional experience and children capacity to deal with difficult emotion (Frude \& Killick, 20I I).

Parents are expected to encourage children to join with multiple ways so that the story telling is more like a dialogue instead of monologue. Within story telling interaction, parents and children share experience. Together they become familiar with the character, follow the story line and emotionally react to the disclosed event. Further, parents and children are aware that they share the same experience toward each other. Parents and children go through the same story together, it tends to make the stories more excited and increase the relationship quality (Frude \& Killick, 20II).

The urgency of this research is to help to establish and maintain the quality of the relationship between parents and children so that it increases secure attachment. It is expected to contribute to the children development. The quality of social involvement between children and figure attachment is more important than the amount of time they spend together. The calming nurturing involvement, entertaining and hugging children are potentially to be happened in the process of storytelling, will encourage the increasing of secure attachment existence (Frude \& Killick, 20I I).

The traditional game story e-book app was arranged through the development of traditional e-book literature (Saputra \& Ekawati, 2018). It is considered unfamiliar by today's children. E-book app consists of stories, be king and queen (playing kuluk, a head cover, and necklace made of cassava leaves); It is fun to play shell sandals (coconut shell); my toy windmill (kitir) looks like an airplane propeller; good driver (a push coconut fiber); giant wood (setinjak/egrang). The series of story in this app are arranged in family setting with the tagline Saturday with Mom and Dad.

There are five characters in the story e-book app including Dad, Mom, Nayo, Emir and Reza. Substantially, story e-book app is arranged as many as 38 pages which contain harmonious 
interaction of each family member playing traditional game such as teamwork to find out the game material, how to make it and how to use the game tools, also the gratitude reflection of the accomplishment of each planned task.

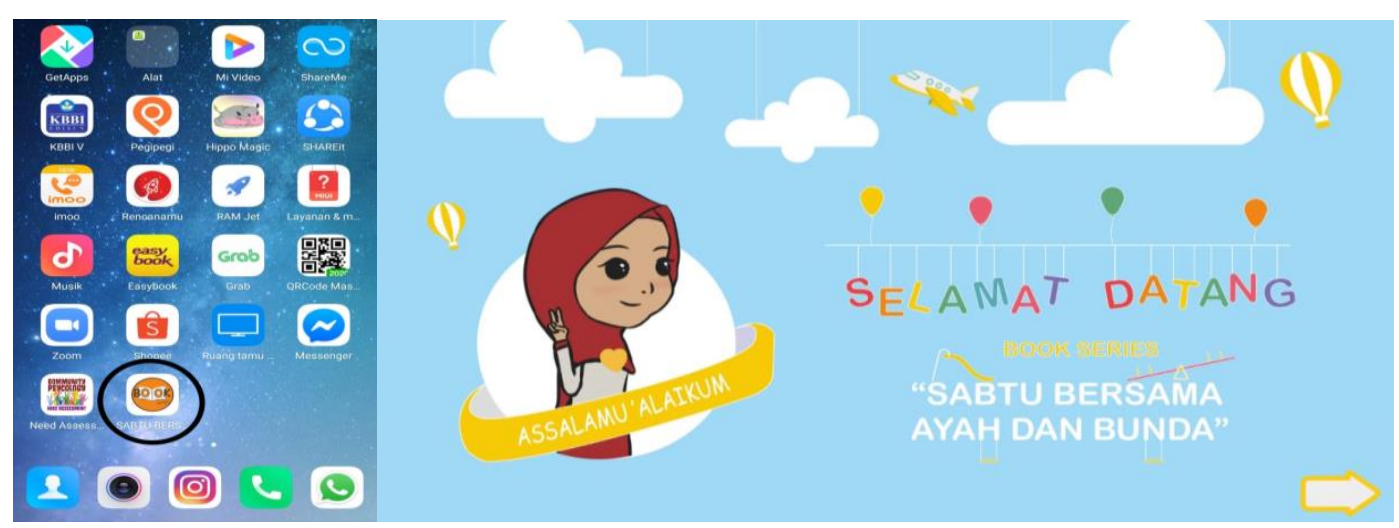

Picture I. Traditional Game Story E-book App

This research does not only design commercial app as a development of traditional game, yet it also becomes an educational media to improve the early childhood abilities and preserve the traditional game existence. The use of e-book (digital book) as story sharing media for preschool age children is expected to encourage every researcher to be focus on the digital media literature development which is capable to explore the children interaction with the e-book format. Children as digital native of often called as iGeneration is a group of generation who live with technology.

The originality of this research lies on local content implementation which are traditional game playing activity as a narration which illustrates the attachment between parent and children. Futher, this research focuses on the story telling implementation to the attachment of parent and children which expect to enrich story telling study that has been done (Bratitsis \& Ziannas, 20I5: Hu et al., 2021 ; Isbell et al., 2004; Pramling \& Pramling Samuelsson, 2008; Rahiem, 2021; Rahim \& Rahiem, 2013), in particular with the using of different software application used in other research (Vinayakumar et al., 2018). 


\section{Method}

Design

The method used is experimental quasi with pre-post control group design. Table I shows experimental quasi design.

Table I

Research design

\begin{tabular}{cccc}
\hline Group & Pretest & Treatment & Posttest \\
\hline EG & OI & $X$ & O2 \\
CG & O1 & - & O2 \\
\hline
\end{tabular}

Description:

EG $=$ Experiment Group

$C G=$ Control Group

$\mathrm{OI}=$ Pretest

$\mathrm{O} 2=$ Posttest

$\mathrm{X}=$ Storytelling Treatment

This research consists of some stages including pretest, treatment and posttest. First, pretest was conducted to figure out g-score attachment of each participant by giving attachment recognition scale to both of the participant groups which were experimental and controlled group. Second, the treatment was only applied to the experimental group meanwhile to the controlled group it was not applied. Story telling activity was done by mother to the kids for five days delivering five traditional game e-book series for 45 minutes long to finish the whole e-book. Third, post test was conducted after the treatment by measuring the recognition attachment scale obtained from each participant both from the experimental group and controlled group.

\section{Participants}

The research participants were $4-6$ years old kindergarten students. Research informed consent was given to parents to participate before the research was conducted. Informed consent contains information about the need of the research toward the participants, including the risk in it, and the researcher responsibility to the negative impact which was obtained and the distribution of compensation to the participant within the research process. Most of the participants were 6 years old (60\%) and boys (64\%). The participants were split into experimental group as many 16 students and controlled group as many as 16 students. 


\section{Data Collection}

The research data collection modified the sub-indicators of attachment scale including I) parentschildren contact; 2) emotional bounding; and 3) parents impression which have reach the reliability score between $0.83-0.94$ (Tanaka, 2020). This scale has been tested to kindergarten students of An-Nahl. It generated 24 valid items with a Cronbach alpha. The reliability of the questioannaire was 0.807 .

Traditional game story e-book series app

App is a software/small computer program which allows the users to do particular tasks (designed). It can be installed and run on many portable digital devices, such as smart phone and tablet (Burgers et al., 2016; C. Z. Liu et al., 2014). The traditional game e-book series app was arranged explaining kuluk game and cassava leaves necklace, shell sandals, kitir-kitir, a push coconut fiber, and setinjak/egrang (Saputra \& Ekawati, 2018).

Traditional game e-book series app was arranged with the support of Smart Apps Creator (SAC) app. SAC is an interactive digital media used to establish multimedia content for mobile devices. This app can be used on loS and Android with output extension covers HTML5 and .exe. It makes this app compatible in every devices and touch screen (smartappscreator.com). The product design with the form of this app is expected to help parents easily use the story book and use the environmentally friendly app (paperless).

The pictures in this story book were arranged and illustrated simple so it will be easy to be understood by children. The color use fits the children's reading and it is followed by the story narration. The picture design explains in 2 pictures below:

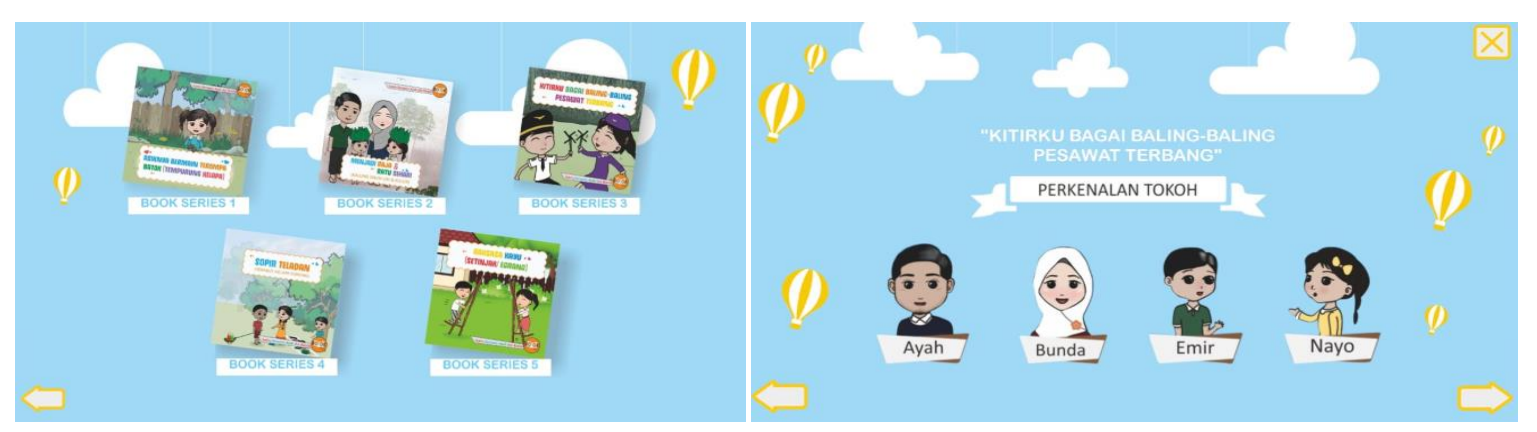

Picture 2. The traditional game story e-book series app picture design 
Table 2

Assessment Result

\begin{tabular}{|c|c|c|c|c|c|c|c|c|}
\hline \multirow{2}{*}{ Criteria } & \multirow{2}{*}{$\begin{array}{l}\text { Assessment } \\
\text { Indicators }\end{array}$} & \multicolumn{3}{|c|}{ Assessor } & \multirow{2}{*}{$\begin{array}{l}\text { Total } \\
\text { Score }\end{array}$} & \multirow{2}{*}{$\sum s$} & \multirow{2}{*}{ V } & \multirow{2}{*}{$\begin{array}{c}\text { Validation } \\
\text { Level }\end{array}$} \\
\hline & & I & 2 & 3 & & & & \\
\hline Content Accuracy & $\begin{array}{l}\text { Includes the values } \\
\text { developed in the } \\
\text { story. }\end{array}$ & 3 & 3 & 4 & 10 & 7 & 0,583 & Medium \\
\hline $\begin{array}{l}\text { Content Coverage } \\
\text { Accuracy }\end{array}$ & $\begin{array}{l}\text { The suitability of the } \\
\text { activities or } \\
\text { behaviors which } \\
\text { appears within the } \\
\text { storybook. }\end{array}$ & 4 & 3 & 3 & 10 & 7 & 0,583 & Medium \\
\hline \multirow[b]{2}{*}{$\begin{array}{l}\text { Story digestibility and } \\
\text { logical presentation }\end{array}$} & Coherent storyline & 3 & 4 & 4 & 11 & 8 & 0,666 & High \\
\hline & $\begin{array}{l}\text { The story is easy for } \\
\text { children to } \\
\text { understand. }\end{array}$ & 2 & 3 & 4 & 9 & 6 & 0,5 & Medium \\
\hline \multirow{3}{*}{ Language Use } & $\begin{array}{l}\text { The sentences are } \\
\text { easy for children to } \\
\text { understand }\end{array}$ & 3 & 3 & 4 & 10 & 7 & 0,583 & Medium \\
\hline & $\begin{array}{l}\text { The word choice is } \\
\text { suitable for children }\end{array}$ & 3 & 3 & 3 & 9 & 6 & 0,5 & Medium \\
\hline & $\begin{array}{l}\text { Many sentences on } \\
\text { each page are } \\
\text { suitable for } \\
\text { children's reading }\end{array}$ & 3 & 2 & 3 & 8 & 5 & 0,416 & Medium \\
\hline \multirow{4}{*}{ Illustration } & $\begin{array}{l}\text { Pictures are } \\
\text { understood by } \\
\text { children }\end{array}$ & 3 & 4 & 4 & 11 & 8 & 0,666 & High \\
\hline & $\begin{array}{l}\text { Pictures and colors } \\
\text { are suitable for } \\
\text { children's reading }\end{array}$ & 4 & 3 & 4 & II & 8 & 0,666 & High \\
\hline & $\begin{array}{l}\text { Pictures match the } \\
\text { message from the } \\
\text { written narration }\end{array}$ & 4 & 4 & 4 & 12 & 9 & 0,75 & High \\
\hline & Attractive cover & 3 & 3 & 4 & 10 & 7 & 0,583 & Medium \\
\hline
\end{tabular}

\section{Procedure}

This research consists of some stages including pretest, treatment and posttest 


\section{Pretest}

Pretest was conducted before the treatment. It aimed to obtain attachment recognition score from the participants before treatment was given.

\section{Treatment}

Treatment was only given to experimental group. The treatment given was traditional game e-book series story telling. It was given to the children for 5 days. The traditional game story e-book series was read to the children for about 50 minutes each day. Picture 3 shows five sections of the story telling.

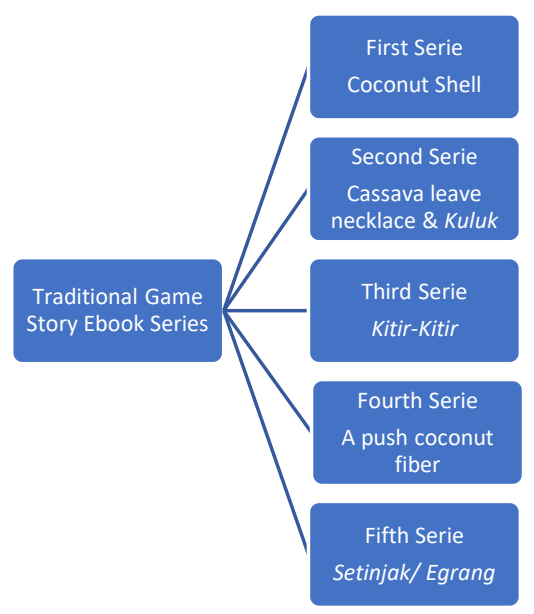

Picture 3. Traditional game story e-book series story telling section

Posttest

Posttest is the collection of data attachment recognition done after the treatment was given to both the experimental group and controlled group. The data collection tool for the posttest used the same scale as which was used in the pretest.

\section{Data Analysis}

Independent t-test sample test and t-test paired test use to examine the research hypothesis with SPSS 16. T-test paired test use to examine the pretest and posttest score gap both in experimental group and controlled group, meanwhile independent t-test sample use to examine the score gap between experimental group and controlled group. 


\section{Result}

The statistical overview of the research result, including mean and standard deviation score of pretest and posttest within the experimental group and controlled group, shows in table 3.

Table 3

Statistical Overview

\begin{tabular}{lllc}
\hline \multicolumn{1}{c}{ Group } & Score & Mean & Standard Deviation \\
\hline Experiment & Pretest & 48.25 & 6.6 \\
& Posttest & 51.06 & 5.2 \\
Control & Pretest & 47.25 & 3.6 \\
& Posttest & 47.56 & 3.1 \\
\hline
\end{tabular}

Picture 4 shows the average pretest-posttest value gap between experimental group and controlled group. The average increase of pretest score to posttest score has been found within the experimental group, meanwhile within the controlled group the average score is relatively the same as the pretest.

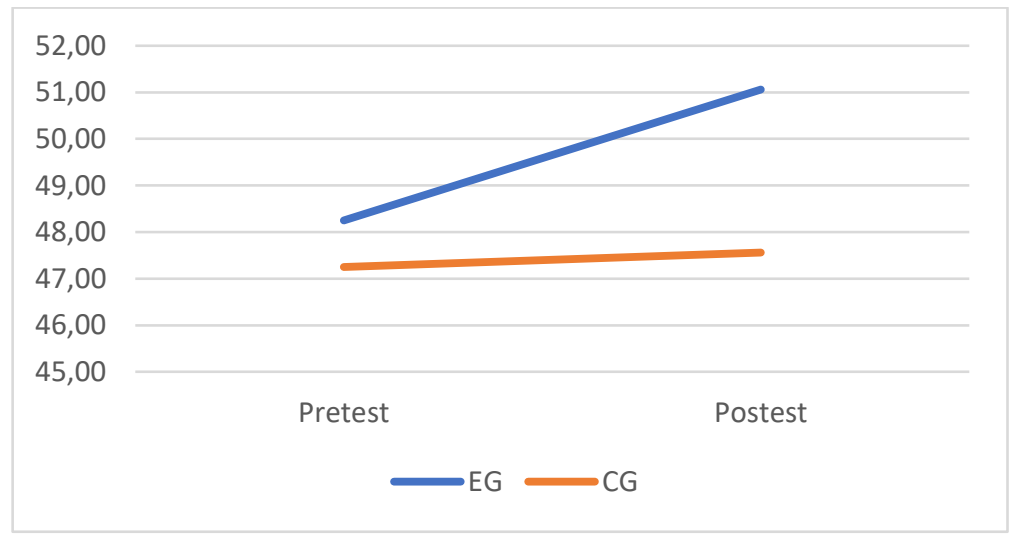

Picture 4. The mean difference of experimental group and controlled group

Table 4 shows data analysis result. Based on the paired t-test, there was significant gap between pretest average score and posttest average score among the participants within the experimental group. The result showed the average posttest score was higher than the average pretest score. 
Therefore, to the experimental group the participant attachment increased after storytelling activity conducted. Otherwise, there was no significant gap between the average of pretest score and the average of posttest score among the participant in the controlled group. The result meant the participant attachment within the controlled group was the same even though there was a little bit reduction of the score. Based on the t-test sample independent test result, there was no gap between average pretest score among the participants within the experimental group and controlled group.

The result showed that the attachment $r$ of participants were not different from the participants of the experimental group with storytelling treatment. Furthermore, the average posttest score in the experimental and controlled group was significantly different. The posttest average score among the participant in the experimental group is higher than the posttest average score among the participant in the controlled group.

Table 4

The t-test Results

\begin{tabular}{lllc}
\hline \multicolumn{1}{c}{ t-test } & \multicolumn{1}{c}{ Variable } & T value & Exact Sig (2-tailed) \\
\hline Paired sample & Pretest EG and Posttest & -2.975 & 0.005 \\
t-test & EG & & \\
& Pretest CG and Posttest & -0.837 & 0.208 \\
& CG & & 0.301 \\
Independent & Pretest EG and Pretest & -0.528 & \\
sample t-test & CG & & 0.015 \\
& Posttest EG and Posttest & -2.277 & \\
\hline
\end{tabular}

\section{Discussion}

Digital story telling has been an option to describe a narration or story (Robin, 2008) to the children. Children will be known as " digital natives" tend to choose digital media (Vinayakumar et al., 2018) which contain a metaphor about a concept which suit to the children intelligent level (Vivitsou, 2018), compare to common printed book. Digital story telling encourage children to 
explore and access many information which obtain from the social environment and could increase communication skill by learning to manage their ideas, asking questions, telling their opinion and establishing narration to interact with others (Frude \& Killick, 20I I; O'Bryrne et al., 20I8). Further, storytelling can help children to explore stories which relate to their emotion they feel. Also to get story which has experienced exchange from others (Sawyer \& Willis, 20II)? It is expected to increase emotional experience and capacity to the children to deal with problems (Frude \& Kilick, 20II).

If children are able to connect the emotional experience and narration expression which obtained through story telling activity, in particular parents (Killick, 2020; Kiser et al., 20I0). Therefore, it is not possible that children are able to have capacity to understand situations which emphasize and respond correctly and take lesson from it (Graci \& Fivush, 2017) Also, it can establish attachment between children and the attached figure well. At the end, "the working model" attachment can grow.

The result of the research showed that storytelling by using traditional game e-book series app can increase the attachment between parents and children. The e-book series app has been delivered as one of android application which could stimulate the attachment between parents and children. This traditional game story e-book series app was arranged to describe the traditional game activity in family setting and the involvement of parents to prepare the equipment of the traditional game together with the children. The step to play the traditional game is through role play and harmonious interaction among family members, also reinforcing the characters of the traditional game activity players.

The material for this app was arranged based on the previous research (Ekawati \& Saputra, 2019; Saputra \& Ekawati, 2017). This e-book series utilize multimedia elements including sound instrument. It is expected to increase child's interest exposed by this story app. This app has been assessed by the assessor including psychologists, cultural figures, and story tellers.

This app fulfilled the validity criteria. The validity criteria were medium and high in each assessment criteria. Content accuracy criteria, content coverage accuracy and language use included in the medium category, meanwhile illustration criteria is in category. The interesting illustration including 
natural picture, text, shapes and color emphasis which suits the children development to make this app be more interesting children to listen and watch. If children are willing to listen, then it is not impossible to be explained that this application was arranged interesting which is suitable to the need of children. Also, it could be a good message delivery media to the children.

Robin (2008) explains that technology in managing story telling media has made this application more interesting and effective in particular to design the picture, adjust the color, and illustrate the content as attractive as possible completed with attractive audio. The message delivered are varied, it gives more change to create better time involving parents and children (Saputra \& Ekawati, 2019).

By reading, children will find secure attachment with parents. The secure attachment related to the more positive feedback from parents to children will encourage children explorative attitude toward the story (Zivan \& Horowitz-Krauz, 2020). Further the involvement of parent through reading activity can educate children (Lucarevschi, 2016; Stavans \& Goldzweig, 2008). Children will learn listening to what was delivered and parents will also get benefit which is confident and satisfaction in nurturing children (Hornby, 20II).

Parents have their own experience and satisfaction when they tell stories to the children (Frude \& Killick, 20I I; Saputra \& Ekawati, 2019). Parents and children who tell each other can establish a fun relationship (Killick, 2020). It could make parents give more attention to the children thus parentschildren relationship will be intimate because of good interaction and communication (Afiatin \& Andayani, 2016; Killick \& Frude, 2009).

The higher attachment quality of parents and children could reduce aggression, and social stress. It also could increase children self- esteem (Ooi et al., 2006). Parents are expected to encourage children to join all the way therefore the storytelling activity will be more like a dialogue instead of monologue. The involvement of parents in particular when having conversation to help and assist children to express their emotion, in particular the negative impact which is expected to help children to establish synergy to reduce emotional problem they are dealing with (Zimmer-Gembeck et. Al., 2017). 
Parents and children will have interaction to share their experience (Killick, 2020). Together they become familiar with the character, following the story line and emotionally react to the scenes revealed. Later, parents and children will be aware that they share the same experiences Parents and children who share the story together tend to make the story more fun and it will increase the quality of relationship (Frude \& Killick, 20II).

Further, storytelling encourages children and parents to discuss about the story topic that can emerge situation and behavior that happen in reality (Phillips et al., 2000). The story narration is normally a representation of good and bad therefore children are expected to take lesson from it (Isik, 2016). Parents and children can explore the story and clarify if there is inappropriate action. Storytelling can make them able to develop deeper understanding about the experiences. When they start to understand that experience therefore internalization happens, and they will be able to fit the behavior and transfer their understanding to the other aspects of life (Sawyer \& Willis, 20II).

This app is expected to help parents to establish and maintain the relationship quality to the children to increase the secure attachment so that it affects the children development. Social involvement quality between children an attachment figures is more important than the amount of time they spend together, Therefore, it is expected to encourage children to develop secure attachment "working model", in which children will take longer time to figure out personality, character and attitude of parents as the attached figure as whole (Ainwort et al., 20I5).

Relaxing nurture, entertaining or hugging children is possibly happen in the storytelling process. It will encourage the establishment of secure attachment (Frude \& Killick, 20I I). This traditional game story e-book series is expected to serve and spread the limited traditional game literatures. The ebook series app is expected can be accessed by anyone and anywhere because this digital media concept is very popular with the society currently. The use of gadget which can be accessed by everyone, not only parents but also children. It increases the chance to develop information about traditional game. 


\section{Conclusion}

The storytelling using the e-book app with five stories related to traditional game has been successfully stimulated the attachment between parents and children. Parents-children contact, emotional bond and parents' impression which perceived by children are the increase of attachment in this research. Participants experience during the storytelling when listening to the story strengthens contact between parents and children. Also, the involvement of parents making time to do storytelling strengthens emotional experience of children toward parents. Therefore, this traditional game story e-book app can be one of tools which useful to increase the involvement of parents to establish and maintain relationship quality with the children through storytelling activity.

\section{Acknowledgements}

This Research has been carried out under the applied research Scheme provided by LP2M Jambi University. The authors would like to extend their gratitude to the School Early Childhood Education Program An-Nahl Jambi, and research validator.

\section{References}

Afiatin, T., \& Andayani, B. (2016). Pelatihan keterampilan mendongeng untuk keluarga nelayan. Jurnal Pengabdian Kepada Masyarakat (Indonesian Journal of Community Engagement), 2(I), 53. https://doi.org//0.22146/jpkm.22217

Ainswort, M. D. S., Blehar, M. C., Everett, W., \& Wall, S. N. (20I5). Pattern of attachement a psychological study of the strage situation. In Psyhology Press. Taylor \& Francis.

Bratitsis, T., \& Ziannas, P. (20I5). From early childhood to special education: interactive digital storytelling as a coaching approach for fostering social empathy. Procedia Computer Science, 67(Dsai), 23I-240. https://doi.org/10.1016/j.procs.2015.09.267

Burgers, C., Eden, A., de Jong, R., \& Buningh, S. (2016). Rousing reviews and instigative images: The impact of online reviews and visual design characteristics on app downloads. Mobile Media and Communication, 4(3), 327-346. https://doi.org/10.1I77/2050I579/6639348

Cassidy, J. (1988). Child-mother attachment and the self in six-year-olds. Child Development, 59(I), I2I-I34. https://doi.org/I0.I I I I/j.| 467-8624.1988.tb03200.x

Ekawati, Y. N., \& Saputra, N. E. (2019). Uji coba modul paket alat permainan edukatif (ape) cengkling/ engklek untuk meningkatkan kemampuan visual spasial anak. Temilnas XI IPPI, 727- 
739. http://psychologyforum.umm.ac.id/files/file/Prosiding IPPI 2019/76_Naskah 727-739.pdf

Frude, N., \& Killick, S. (20I I). Family storytelling and the attachment relationship. Psychodynamic Practice, I 7(4), 44 I-455. https://doi.org/I0.I080/I4753634.20II.609025

Graci, M. E., \& Fivush, R. (2017). Narrative meaning making, attachment, and psychological growth and stress. Journal of Social and Personal Relationships, 34(4), 486-509. https://doi.org/ 0.1 177/0265407516644066

Hill, D., Ameenuddin, N., Chassiakos, Y. R., Cross, C., Radesky, J., Hutchinson, J., Boyd, R., Mendelson, R., Moreno, M. A., Smith, J., \& Swanson, W. S. (2016). Media and young minds. Pediatrics, 138(5). https://doi.org//0.1542/peds.2016-259I

Holmes, J., \& Holmes, J. (20I4). John Bowlby and attachment theory. In John Bowlby and Attachment Theory. https://doi.org/I0.4324/978I 3 I 5879772

Hornby, G. (20I I). Parental involvement child education. In Journal of Chemical Information and Modeling (Vol. 53, Issue 9).

Hu, J., Gordon, C., Yang, N., \& Ren, Y. (202I). “Once upon a star”: a science education program based on personification storytelling in promoting preschool children's understanding of astronomy concepts. Early Education and Development, 32(I), 7-25.

https://doi.org/ I0.1080/10409289.2020.17590 I I

Isbell, R., Sobol, J., Lindauer, L., \& Lowrance, A. (2004). The effects of storytelling and story reading on the oral language complexity and story comprehension of young children rebecca. Early Childhood Education Journal, 32(3), I57-163.

Isik, M. A. (2016). The impact of storytelling on young ages. European Journal of Language and Literature, 6(I), II5. https://doi.org/I0.264I7/ejls.v6il.pI I5-II8

Jiao, W. Y., Wang, L. N., Liu, J., Fang, S. F., Jiao, F. Y., Pettoello-Mantovani, M., \& Somekh, E. (2020). Behavioral and emotional disorders in children during the COVID-19 Epidemic. Journal of Pediatrics, 22I, 264-266.el. https://doi.org/I0.10I6/j.jpeds.2020.03.013

Kabali, H. K., Irigoyen, M. M., Nunez-Davis, R., Budacki, J. G., Mohanty, S. H., Leister, K. P., \& Bonner, R. L. (2015). Exposure and use of mobile media devices by young children. Pediatrics, I36(6), I044-1050. https://doi.org/I0.I542/peds.20I5-2I5 I

Kerns, K. A., \& Brumariu, L. E. (20I4). Is insecure parent-child attachment a risk factor for the development of anxiety in childhood or adolescence? Child Development Perspectives, 8(I), I2I7. https://doi.org/I0.1 I I I/cdep. 12054

Killick, S. (2020). Building Relationships through Storytelling A foster carer's guide to. September 20 I 2.

Killick, S., \& Frude, N. (2009). The teller, the tale and the told - the psychology of storytelling. Psychologist, 22(10).

Kiser, L. J., Baumgardner, B., \& Dorado, J. (2010). Who are we, but for the stories we tell: Family 
stories and healing. Psychological Trauma: Theory, Research, Practice, and Policy, 2(3), 243-249. https://doi.org/10.1037/a0019893

Lee, A., \& Hankin, B. L. (2009). Insecure attachment, dysfunctional attitudes, and low self-esteem predicting prospective symptoms of depression and anxiety during adolescence. Journal of Clinical Child and Adolescent Psychology, 38(2), 219-231.

https://doi.org/I0.1080/15374410802698396

Liu, C. Z., Au, Y. A., \& Choi, H. S. (20I4). Effects of freemium strategy in the mobile app market: an Empirical study of google play. Journal of Management Information Systems, 3 I(3), 326-354. https://doi.org// 0.1080/07421222.2014.995564

Liu, J. J., Bao, Y., Huang, X., Shi, J., \& Lu, L. (2020). Mental health considerations for children quarantined because of COVID- 19. The Lancet Child and Adolescent Health, 4(5), 347-349. https://doi.org// 0.1016/S2352-4642(20)30096-I

Lucarevschi, C. R. (2016). The role of storytelling on language learning: A literature review. Working Papers of the Linguistics Circle of the University of Victoria, 26(I), 24-44.

https://search.proquest.com/docview/ 886242426?accountid=I 5 I81\%0Ahttp://openurl.york.ac. uk/openurl/44YORK/44YORK_services_page?url_ver=Z39.88-

2004\&rft_val_fmt=info:ofi/fmt:kev:mtx:journal\&genre=article\&sid=ProQ:ProQ\%3Allba\&atitle= The+role+of+storytelling+

Maynard, S. (2010). The impact of e-books on young children's reading habits. Publishing Research Quarterly, 26(4), 236-248. https://doi.org/10.1007/s I 2 109-010-9/80-5

O’Byrne, W. I., Stone, R., \& White, M. (2018). Digital storytelling in early childhood: Student illustrations shaping social interactions. Frontiers in Psychology, 9(OCT), I-I4.

https://doi.org/l0.3389/fpsyg.2018.01800.

Ooi, Y. P., Ang, R. P., Fung, D. S. S., Wong, G., \& Cai, Y. (2006). The impact of parent-child attachment on aggression, social stress and self-esteem. School Psychology International, 27(5), 552-566. https://doi.org//0.1 I77/0143034306073402.

Parish-Morris, J., Mahajan, N., Hirsh-Pasek, K., Golinkoff, R. M., \& Collins, M. F. (20I3). Once upon a time: Parent-child dialogue and storybook reading in the electronic era. Mind, Brain, and Education, 7(3), 200-2 II. https://doi.org/I0.1 I I I/mbe. 12028

Phillips, L., Gowrie, Lady, \& Centre, C. (2000). Storytelling: The seeds of children's creativity. 25(3), I5.

Pramling, N., \& Pramling Samuelsson, I. (2008). Identifying and solving problems: Making sense of basic mathematics through storytelling in the preschool class. International Journal of Early Childhood, 40(I), 65-79. https://doi.org/I0.1007/BF03/68364

Rahiem, M. D. H. (202I). Storytelling in early childhood education: Time to go digital. International Journal of Child Care and Education Policy, I5(I). https://doi.org/I0.I I86/s40723-02 I-0008I-X

Rahim, H., \& Rahiem, M. D. H. (20I3). The use of stories as moral education for young children. 
International Journal of Social Science and Humanity, 2(6), 454-458. https://doi.org//0.7763/ijssh.2012.v2.145

Rajkumar, R. P. (2020). Attachment theory and psychological responses to the covid-19 pandemic: A narrative review. Psychiatria Danubina, 32(2), 256-26I. https://doi.org// 0.24869/PSYD.2020.256

Robin, B. R. (2008). Digital storytelling: A powerful technology tool for the 21 st century classroom. Theory into Practice, 47(3), 220-228. https://doi.org/I0.1080/00405840802I539I6

Saputra, N. E., \& Ekawati, Y. N. (20I7). Meningkatkan kemampuan dasar anak tradisional games in improving children's basic abilities. Jurnal Psikologi Jambi, 2(2), 48-53.

Saputra, N. E., \& Ekawati, Y. N. (2018). praktikalitas buku saku digital (digital book pocket ) APE tradisonal. Seminar Nasional Psikologi Unissula: Penguatan Keluarga Di Zaman Now, I I5-126. http://jurnal.unissula.ac.id/index.php/psnpu/article/view/3793

Saputra, N. E., \& Ekawati, Y. N. (2019). Uji validitas buku elektronik (Ebook) cerita permainan tradisional (menjadi raja dan ratu sehari) dalam meningkatkan .... Temilnas XI IPPI, 462-473. http://psychologyforum.umm.ac.id/files/file/Prosiding IPPI 2019/50_Naskah 462-473.pdf

Sawyer, C. B., \& Willis, J. M. (20I I). Introducing digital storytelling to influence the behavior of children and adolescents. Journal of Creativity in Mental Health, 6(4), 274-283. https://doi.org/I0.1080/15401383.201 I.630308

Stavans, A., \& Goldzweig, G. (2008). Parent-child-adult storytelling. Narrative Inquiry, I8(2), 230257. https://doi.org/I0.1075/ni.18.2.04sta

Tanaka, Y. (2020). The development of a parental attachment recognition scale for mothers nurturing preschool children. Public Health Nursing, 37(2), 310-320. https://doi.org/10.1 III/phn.I2697

Van Gelder, N., Peterman, A., Potts, A., O’Donnell, M., Thompson, K., Shah, N., \& Oertelt-Prigione, S. (2020). COVID- 19: Reducing the risk of infection might increase the risk of intimate partner violence. EClinicalMedicine, 2 I, I00348. https://doi.org/I0.1016/j.eclinm.2020.100348

Verschueren, K., Marcoen, A., \& Schoefs, V. (1996). The Internal Working Model of the Self, Attachment, and Competence in Five-Year-Olds. Child Development, 67(5), 2493-25II. https://doi.org/I0.1 II I/j.1467-8624.1996.tb01870.x

Vinayakumar, R., Soman, K., \& Menon, P. (2018). Digital storytelling using scratch: Engaging children towards digital storytelling. 2018 9th International Conference on Computing, Communication and Networking Technologies, ICCCNT 2018, March 2020. https://doi.org/I0.1 I09/ICCCNT.2018.849394 I

Vivitsou, M. (2018). Digital storytelling in teaching and research. SSRN Electronic Journal, January. https://doi.org//0.2139/ssrn.310847|

Yelland, N., \& Masters, J. (2007). Rethinking scaffolding in the information age. Computers and 
Education, 48(3), 362-382. https://doi.org/I0.1016/j.compedu.2005.01.010

Zimmer-Gembeck, M. J., Webb, H. J., Pepping, C. A., Swan, K., Merlo, O., Skinner, E. A., Avdagic, E., \& Dunbar, M. (2017). Review: Is parent child attachment a correlate of childrens emotion regulation and coping? International Journal of Behavioral Development, 4I(I), 74-93.

https://doi.org/10.1177/0165025415618276

Zivan, M., \& Horowitz-Kraus, T. (2020). Parent-child joint reading is related to an increased fixation time on print during storytelling among preschool children. Brain and Cognition, I43(May), 105596. https://doi.org/I0.1016/j.bandc.2020.105596

Smartappscreator.com. Overview Smart Apps Creator. Diakses I5 Agustus 2020 